Journal of Agrometeorology 23 (3) : 310-315 (September 2021)

\title{
Potato late blight disease prediction using meteorological parameters in Northern Himalayas of India
}

\author{
W. A. DAR* F. A. PARRY and B. A. BHAT \\ Mountain Agriculture Research and Extension Station, Gurez \\ Sher-e-Kashmir Univ of Agril Sciences and Technology of Kashmir, India \\ *Corresponding Author: luckywasim2017@gmail.com
}

\begin{abstract}
Weather parameters play an important role in the spread of potato late blight of caused by Phytophthora infestans (Mont.) de Bary has historically been serious disease of potatoes through worldwide, including India. Due to spatial variation in prevailing weather conditions, its severity varies from region to region. Disease development process and the weather parameters are well understood and have been utilized for disease developing forecasting models and decision support system. Therefore, an experiment was conducted for two consecutive cropping seasons (2017 \& 2018) to develop a forecasting model against late blight of potato using stepwise regression analysis for Northern Himalayas in India. Maximum and minimum temperature, relative humidity, rainfall and wind speed appeared to be most significant factors in the potato late blight disease development. The meteorological conditions conducive for the development of potato late blight disease were characterized. Maximum and minimum temperatures in the range of $15.0-$ $28.0^{\circ} \mathrm{C}$ and $2.0-12.0^{\circ} \mathrm{C}$ were found favorable for potato blight disease. Similarly, relative humidity, rainfall and wind speed in the range of 85 - 95 per cent, $15.5-20.75 \mathrm{~mm}$ and $1.0-5.5 \mathrm{Km} \mathrm{h}^{-1}$, respectively, were conducive for potato late blight disease which are helpful in disease development.
\end{abstract}

Key words: Environmental factors; potato late blight; Phytophthora infestans

Late blight of potato is caused by Phytophthora infestans (Mont.) de Bary, is a devastating disease of major concern all over the world which causes heavy losses of potato. Phytophthora infestans is a water mold lower fungus, and infects potato crop via seed and soil during cool and wet weather. Infection of shoots can be caused by mycelium growing from the tuber into the developing shoot or via sporangia and zoospores formed on the tuber surface under moist conditions. Phytophthora infestans has a worldwide distribution and is found wherever potatoes are grown (Goss et al., 2014). The severity of a potato late blight disease outbreak is strongly influenced by prevailing environmental conditions on the pathogen lifecycle and its aggressiveness within the local pathogenic population (Doster, 1989). Economic importance of this disease in different regions resulted that the disease takes the highest toll of potato in Sub-Saharan Africa (44\% crop loss) followed by South-East Asia (35\% crop loss).

Potato late blight management has always been a challenge for both scientists and farming community. For effective management of potato late blight, efforts should be made to slow down the disease progress particularly reduction in the initial inoculum. There is a need to develop forecast/warning services for predicting the time of appearance of disease and optimizing use of fungicides without risking the crop and human health. These models predict outbreak or changes in intensity of one or more diseases on the basis of weather information, crop, pathogens (Shtienberg, 2010). In India, Singh et al., (2000) developed location specific computerized forecast model (JHULCAST) for Western U.P. using hourly temperature $\left({ }^{\circ} \mathrm{C}\right)$, relative humidity (\%) and daily precipitation $(\mathrm{mm})$ as input parameters. Since then the model has been calibrated for predicting late blight appearance in Punjab (Arora et al., 2012) and Tarai region of Uttarakhand (Pundhir et al., 2014). Therefore, the present investigations has been undertaken to study the correlation between potato late blight disease and environmental variables and to develop disease prediction model through multiple regression for timely management of disease. Present examinations will help to forecast the late blight of potato in Northern Himalaya in India and assist the growers for spray schedule and reduces the costs involved by eliminating the unnecessary sprays and 
labour cost.

\section{MATERIAL AND METHODS}

The field experiment was carried out during 2017 and 2018 at the research field at Mountain Agriculture Research and Extension Station (MAR\&ES), Gurez, SKUAST-Kashmir, India, situated at latitude $34^{0} 38^{\mathrm{I}}$ $1.57^{\text {II }} \mathrm{N}$ and longitude $74^{\circ} 50^{\mathrm{I}} 25.27^{\mathrm{II}} \mathrm{E}$ with an altitude of $2430 \mathrm{~m}$ amsl. The area is characterized by a cold altitude climate with one crop season (May-October): long rainy days from May-August and short semi dry from September to October. The present study was taken for two consecutive growing seasons 2017 \& 2018 from $1^{\text {st }}$ week of June to $2^{\text {nd }}$ week of October in each year.

Potato tubers of three release varieties (Kufri Jyoti, Shalimar Potato-I, Gulmarg Special) and a local check (Gurez local) were used for the experiment. The experiment was laid down in Randomized Complete Block Design with three replications in tested cultivar. Distance between plant to plant was $30 \mathrm{~cm}$ and row to row was $75 \mathrm{~cm}$ in a single plot $(2.0 \mathrm{~m} \times 3.0 \mathrm{~m})$.

The disease severity data was recorded at 7 days interval from initiation of symptoms with the help of four-level scale based on area under the disease progress curve (Jenkins and Jones, 2003). The area under disease progress curve (AUDPC) was calculated for each variety/ plot from the severity data using mid-point method (Campbell and Madden, 1990). Daily meteorological data viz., maximum temperature, minimum temperature, relative humidity, rainfall and wind speed was obtained from Snow and Avalanche Study Establishment (SASE) Kanzalwan, Gurez (J\&K), India.

Percent disease severity was measured with the following formula:

$$
\text { Per cent severity of PLB }=\frac{\begin{array}{c}
\text { No. of diseased } \\
\text { leaves/plant }
\end{array}}{\begin{array}{c}
\text { Total No. of leaves/ } \\
\text { plants assessed }
\end{array}} \times 100
$$

AUDPC values for each variety were computed based on lesion number and per cent leaf area covered data. The calculation was made, employing formula proposed by Wilcoxson et al. (1975).

$$
\operatorname{AUDPC}=\sum_{\mathrm{i}=1}^{\mathrm{n}}\left[(S i+S i-1) \times 0.5\left(t_{2}-t_{1}\right)\right]
$$

Where, $\mathrm{Si}=$ Amount of disease at $\mathrm{i}^{\text {th }}$ time, $\mathrm{i}$ ranges from 1 to $n ; S_{i-1}=$ Amount of disease at $(\mathrm{i}-1)^{\text {th }}$ time. ; $\mathrm{t}_{2}-\mathrm{t}_{1}=$ Number of days between two observations.; $\mathrm{n}=$ Number of successive evaluation of disease

The data recorded was analyzed using SPSS v.17 (statistical software). Correlation between environment parameters (maximum temperature, minimum temperature, rainfall, relative humidity and wind speed) and disease severity were determined by correlation analysis. Disease predicting model for potato late blight based on two years environmental variables was developed using step wise regression analysis. Before subjecting the data to regression analysis, to help standardize AUDPC values across years, the metric was converted into the relative AUDPC (rAUDPC) as described (Fry et al., 1983). Then the regression models were applied for analyzing the effects of weather parameters on disease progress. The prediction equation and stepwise multiple regression analysis was done by using the following:

$$
\hat{\mathrm{Y}}=\mathrm{a}+\mathrm{b}_{\mathrm{i}} \mathrm{x}_{\mathrm{i}}+\mathrm{e}
$$

Where, $\hat{\mathrm{Y}}=$ predicted severity; $\mathrm{a}=$ intercept; bi $=$ regression coefficient for $x i(i=1$ to $\ldots n)$; $x i=$ independent variables $(\mathrm{i}=1 \ldots \mathrm{n})$; $\mathrm{e}=$ random error.

Multiple regression models was evaluated by the co-efficient of determination $\left(\mathrm{R}^{2}\right)$ and correlation coefficient (r), regression coefficient, test for significance of regression co-efficient, standard error and residual sum of squares (RSS).

\section{RESULTS AND DISCUSSION}

\section{Weather parameters and their influence on severity on late blight}

Potato tubers were planted in the first week of June in 2017 and 2018. The crop was grown and maintained according to the standard organic agronomic management practices and was observed regularly for initiation of late blight symptoms. Disease initiated at pre-flowering stage (35 days after planting) during the $2^{\text {nd }}$ week of July in both the cropping seasons (2017 and 2018). Disease progresses with the passage of time. Weather parameters for the two consecutive years (2017 and 2018) were collected for correlation and prediction model. Minimum temperature 130C and 15.5 along with minimum relative humidity $75 \%$ and $78 \%$ was recorded in the early stages of infection process and maximum temperature 28 and 30.6 along with 
Table 1: Correlation of weather parameters with potato late blight disease severity

\begin{tabular}{lccccc}
\hline \multicolumn{1}{c}{ Varieties } & Max. temperature & Min. temperature & Rainfall & Relative humidity & Wind speed \\
\hline Kufri Jyoti & $0.751^{*}$ & $0.0565^{*}$ & $0.122^{*}$ & $0.673^{*}$ & $0.332^{*}$ \\
Shalimar potato-I & 0.001 & 0.091 & 0.019 & 0.017 & 0.150 \\
& $0.767^{*}$ & $0.550^{\mathrm{NS}}$ & $0.133^{*}$ & $0.64^{*}$ & $0.307^{*}$ \\
Gulmarg special & 0.021 & 0.080 & 0.036 & 0.038 & 0.26 \\
& $0.768^{*}$ & $0.529^{*}$ & $0.114^{*}$ & $0.644^{*}$ & $0.296^{*}$ \\
Gurez local & 0.009 & 0.720 & 0.036 & 0.037 & 0.360 \\
& $0.795^{*}$ & $0.543^{\mathrm{NS}}$ & $0.115^{*}$ & $0.660^{*}$ & $0.264^{*}$ \\
\hline
\end{tabular}

$*=$ Significant $\mathrm{P}<0.05, \mathrm{NS}=$ Non-Significant

Table 2: Coefficient of variables, standard error, t stat, p-value and level of their significance

\begin{tabular}{lcccc}
\hline \multicolumn{1}{c}{ Variable } & Parameter estimate & Standard error & T stat & P-Value \\
\hline Intercept & 6.5 & 3.6 & 6.9 & $0.0001^{*}$ \\
Maximum temperature ${ }^{0} \mathrm{C}$ & 0.45 & 0.18 & -2.5 & $0.023^{*}$ \\
Minimum temperature ${ }^{0} \mathrm{C}$ & 0.02 & 0.12 & 0.2 & $0.008^{*}$ \\
Rainfall (mm) & 0.05 & 0.02 & 2.4 & $0.030^{*}$ \\
Relative humidity (\%) & 0.13 & 0.04 & -3.6 & $0.003^{*}$ \\
Wind speed $\left(\mathrm{km} \mathrm{h}^{-1}\right)$ & 0.38 & 0.36 & 1.0 & $0.03^{*}$ \\
\hline
\end{tabular}

* Significant at $\mathrm{P}<0.05$

relative humidity $95.5 \% 97.5 \%$ was recorded at the time harvesting stage of the crop 2017 \& 2018, respectively. Maximum rainfall i.e. $185.5 \mathrm{~mm} 175.5 \mathrm{~mm}$ and lowest rainfall i.e. $55.5 \mathrm{~mm}$ and $30.4 \mathrm{~mm}$ were received during the early and harvesting stages of crop in 2017 and 2018, respectively. Analysis of the weather parameters infers that high temperature, high relative humidity, rainfall and wind speed play an important role in the progress of late blight of potato. Disease severity was initiated in the $5^{\text {th }}$ week after transplanting and reached maximum (Kufri Jyoti 60.5 \& 56.4 per cent, S. potato 63.3 \& 60.2 per cent, G. Special 65.5 \& 63.5 per cent and Local 73.5 \& 68.6 per cent) in both the cropping seasons 2017 and 2018, respectively. During the dry weather, the progress of the disease was slow whereas under moist conditions humidity increases which cause prompt increase of late blight in potato. It is reported that maximum temperatures $\left(36.9^{\circ} \mathrm{C}\right.$ \& $38.1^{\circ} \mathrm{C}$ ), relative humidity ( $94 \%$ \& $\left.96.4 \%\right)$ exhibited strong positive relationship and influenced the occurrence alternaria leaf blight severity in cotton (Bhattiprolu and Monga, 2018) and in makhana (Santosh et al., 2021).

There was not wide range in resistance reactions among varieties tested with having rAUDPC values less than 0.2 in resistant variety and between $0.6-0.8$ in most of the other varieties. There was a good distribution between high and low values, with several having intermediate values. Yearly average of rAUDPC values indicated that the varieties had similar relative resistance levels in both the years but had slightly higher rAUDPC values in the first year due to more rainy events. The findings were in accordance with the results reported by Das et al., 2011 that variation in environmental variables affected the potato blight disease. Cool weather $\left(12-15^{\circ} \mathrm{C}\right)$ and high humidity ( $>90 \%$ ) with heavy dewfall or rains alternating with warm winds favor the rapid development of fungal foliar disease of potato (Lal et al., 2016). The timing and duration of each event is very important and the relationship between the disease development and meteorological factors were the main components of disease forecasting system.

A significant correlation of potato late blight severity with maximum temperature, minimum temperature, rainfall and relative humidity was found with all the tested varieties during two cropping seasons of 2017 and 2018 (Table 1). Multiple regression model developed on the basis of coefficient of determination 
Table 3: Multiple regression equation based on environmental conditions and predicted potato late blight disease severity values

\begin{tabular}{|c|c|c|c|c|c|c|c|}
\hline Regression equations of PLB disease severity (\%) & Observed & Predicted & t-Value & $\begin{array}{l}\text { Std. error of } \\
\text { prediction }\end{array}$ & $\begin{array}{l}\text { Margin } \\
\text { of error }\end{array}$ & $\begin{array}{l}\text { Lower } \\
\text { bound }\end{array}$ & $\begin{array}{l}\text { Upper } \\
\text { bound }\end{array}$ \\
\hline Kufri Jyoti $\left(Y=4.88+0.37 \mathrm{X}_{1}+0.045 \mathrm{X}_{2}+0.11 \mathrm{X}_{3}\right)$ & 4.03 & 4.21 & 2.16 & 0.80 & 0.56 & 3.56 & 4.77 \\
\hline \multirow[t]{2}{*}{ Shalimar Potato-I $\left(\mathrm{Y}=5.68+0.47 \mathrm{X}_{1}+0.043 \mathrm{X}_{2}+0.12 \mathrm{X}_{3}\right)$} & 4.35 & 5.36 & 2.16 & 0.87 & 1.89 & 3.47 & 7.26 \\
\hline & 4.51 & 4.90 & 2.16 & 0.88 & 1.90 & 3.00 & 6.80 \\
\hline Gulmarg Special $\left(\mathrm{Y}=4.38+0.56 \mathrm{X}_{1}+0.046 \mathrm{X}_{2}+0.12 \mathrm{X}_{3}\right)$ & 4.46 & 5.42 & 2.16 & 0.97 & 2.09 & 3.33 & 7.51 \\
\hline \multirow[t]{2}{*}{ Gurez Local $\left(Y=7.18+0.55 X_{1}+0.050 X_{2}+0.12 X_{3}+0.36 X_{4}\right)$} & 4.92 & 4.55 & 2.16 & 0.97 & 2.09 & 2.46 & 6.64 \\
\hline & 5.02 & 3.75 & 2.16 & 0.93 & 2.02 & 1.73 & 5.76 \\
\hline
\end{tabular}

$\mathrm{X}_{1}=$ Maximum temp; $\mathrm{X}_{2}=$ Rainfall; $\mathrm{X}_{3}=\mathrm{RH} ; \mathrm{X}_{4}=$ Wind speed; $*$ = Significant $\mathrm{P}<0.05$

Table 4: Summary of stepwise regression model developed to predict potato late blight disease with respect to environmental factors on potato varieties during two years 2017 and 2018

\begin{tabular}{|c|c|c|c|c|c|c|c|c|}
\hline \multirow[t]{2}{*}{ Potato varieties } & \multirow[t]{2}{*}{$\mathrm{R}^{2}$} & \multirow[t]{2}{*}{ Adj. $R^{2}$} & \multirow[t]{2}{*}{ Mallows Cp } & \multirow[t]{2}{*}{ RMSE } & \multicolumn{4}{|c|}{$\operatorname{Pr}>F$} \\
\hline & & & & & Maximum temp. & Rainfall & $\mathrm{RH}$ & Wind speed \\
\hline Kufri Jyoti & 0.82 & 0.73 & 3.8 & 0.58 & $0.016^{*}$ & $0.001^{*}$ & $0.012^{*}$ & \\
\hline Shalimar Potato-I & 0.79 & 0.70 & 3.2 & 0.69 & $0.010^{*}$ & $0.002 *$ & $0.021^{*}$ & \\
\hline Gulmarg Special & 0.81 & 0.74 & 3.0 & 0.78 & $0.003^{*}$ & $0.002^{*}$ & $0.022^{*}$ & \\
\hline Gurez Local & 0.82 & 0.73 & 2.6 & 0.77 & $0.005^{*}$ & $0.002 *$ & $0.022^{*}$ & $0.042 *$ \\
\hline
\end{tabular}

$*=$ Significant $\mathrm{P}=0.05$

$\mathrm{R}^{2}$ (maximum value), mean square error MSE (minimum value) and Mallows $\mathrm{Cp}$ ( $\mathrm{p}=$ number of regressor variables in the model). The model statistically justified, $\mathrm{R}^{2}=0.80$ at $P<0.05$, C (p) $=3.8$ and MSE $=0.78$ was used to predict the probable attack of PLB disease under a set of given environmental variables given as under:

$$
\mathrm{Y}=6.5+0.45 \mathrm{x}_{1}+0.02 \mathrm{x}_{2}+0.05 \mathrm{x}_{3}+0.13 \mathrm{x}_{4}+0.38 \mathrm{X}_{5} ; \mathrm{R}^{2}=0.82
$$

Where $\mathrm{Y}=$ Potato late blight disease severity; $\mathrm{x}_{1}=$ maximum temperature; $\mathrm{x}_{2}=$ minimum temperature; $\mathrm{x}_{3}=$ rainfall, $\mathrm{x}_{4}=$ relative humidity and $\mathrm{x}_{5}=$ wind speed.

It is evident from the model that major factors responsible for the occurrence of potato late blight disease were maximum temperature, minimum temperature, rainfall and wind speed prevalent at that time. It indicated that with one unit change in maximum temperature, minimum temperature, rainfall, relative humidity and wind speed there would be probable change of $0.45,0.02$, $0.05,0.13$ and 0.38 units in potato late blight disease severity, respectively. The participation of wind speed would be so significant in disease prediction (Table 2).
Forecasts in certain regions are developed in response to specific cultural procedure adopted, prevailing environment of that region and to grower's responses in that region. It is well established fact of forecast that work well in some locations, may not work in other locations (Singh et al., 2000). Thus, the region specific models with significant variables were developed by stepwise regression on four potato varieties separately to predict potato late blight disease severity during two years. Out of five variables used, three of them viz., maximum temperature, rainfall and relative humidity exerted significant influence in the development of disease actively while minimum temperature and wind speed appeared as the main contributing meteorological variables in the stepwise regression analysis. When these three meteorological variable models were used to predict potato late blight disease severity, there was a fairly good $R^{2}$ value, low $C$ (p) value and low RMSE value obtained (Table 3). During two years of period, all the four varieties performed similarly with small variation in the meteorological conditions. As the maximum and 
minimum temperature increased from $15^{\circ} \mathrm{C}$ to $28^{\circ} \mathrm{C}$ and $2^{\circ} \mathrm{C}$ to $12^{\circ} \mathrm{C}$, respectively, the disease severity also increased. Maximum and minimum temperatures in the range of $15-28^{\circ} \mathrm{C}$ and $2-12^{\circ} \mathrm{C}$, respectively were found favourable for potato blight disease. Similarly, relative humidity, rainfall and wind speed in the range of 85-95 per cent, 15.5-20.75 $\mathrm{mm}$ and 1-5.5 $\mathrm{Kmh}^{-1}$, respectively were conducive for potato late blight disease. Initially significant correlation was observed between relative humidity and disease development. Maximum disease severity was observed at 90 per cent relative humidity in Gurez local variety. Weather conditions favorable for disease development were characterized during two years (2017 and 2018). Maximum and minimum temperatures in the range of $15-28^{\circ} \mathrm{C}$ and $10.0-12.5^{\circ} \mathrm{C}$ were found favorable for blight disease.

\section{CONCLUSION}

The findings of the present study reveal that three weather parameters i.e. temperature (maximum and minimum), relative humidity (morning and evening) and rainfall significantly influences the late blight of potato in Northern Himalayas. High disease severity of potato late blight was recorded during peak periods of humidity (August and September). Increase in temperature along with relative humidity (90\%) confers more congenial factors for disease progress. Therefore, formulated disease prediction model may predict the severity of potato late blight for Northern Himalayas particularly for high altitude. Present data and their analysis may further guide the researchers to devise and develop management strategies for late blight of potato in the hilly temperate region.

\section{ACKNOWLEDGEMENTS}

Authors acknowledge the financial support of Directorate of Research, Sher-e-Kashmir University of Agricultural Sciences and Technology of Kashmir (J\&K)India, to undertake the present study and Mountain Agriculture Research and Extension Station, Gurez for technical support in the execution of the research experiment.

Conflict of Interest Statement : The author(s)declare(s) that there is no conflict of interest.

Disclaimer : The contents, opinions, and views expressed in the research article published in the Journal of
Agrometeorology are the views of the authors and do not necessarily reflect the views of the organizations they belong to.

Publisher's Note : The periodical remains neutral with regard to jurisdictional claims in published maps and institutional affiliations.

\section{REFERENCES}

Andrade-Piedra J.L, Hijmans R.J, JuÃ ${ }_{j}$ rez H.S, Forbes G.A and Shtienberg D. (2005). Simulation of potato late blight in the Andes. Validation of the late blight model. J. Phytopathol., 95: 12001208.

Arora R. K, Ahmad I. and Singh B.P. (2012). Forecasting late blight of potato in Punjab using JHULSACAST model. Potato J., 39(2): 173-176.

Bhattiprolu, S.L. and Monga, D. (2018). Effect of weather parameters on the development of alternaria leaf spot and grey mildew in cotton. J. Agrometeorol., 20(4):315- 318.

Campbell C.L and Madden L.V. (1990). Introduction to plant disease epidemiology. New York: John Wiley and Sons.

Doster M.A, Sweigaird J.A and Fry W.E. (1989). The influence of host resistance and climate on the initial appearance of foliar late blight of potato from infected seed tubers. Am. Potato J., 66: 227-233.

Fry W.E, Apple A.E and Bruhn J.A., (1983). Evaluation of potato late blight forecast modified to incorporate host resistance and fungicide weathering. $J$ Phytopathol., 73: 1054-1059.

Goss E.M, Tabima J.F, Cooke D.E.L, Restrepo S, Fry W.E and Forbes G.A. (2014). The Irish potato famine pathogen Phytophthora infestans originated in central Mexico rather than the Andes. Proc Natl Acad Sci U S A., 111: 8791-8796.

Grenwald, N.J, Rubio-Covarrubias, O. and Fry, W.E. (2000). Potato late blight management and dissemination system using an automated weather monitoring network. Pp. 209-213.

Jenkins J.C and Jones R.K. (2003). Classifying the relative host reaction in potato cultivars and breeding 
lines to the US-8 strain of Phytophthora infestans in Minnesota. Plant Dis., 87:983-990

Lal, M., Arora R.K, Uma M., Rawal S. and Yadav S. (2016). Impact of late blight occurrence on potato production during 2013-14. Int. J. Agric. Stat. Sci., 1(12):187-192.

Pundhir V.S., Singh B.P., Ahmas I, Sharma S., Khushwala H.S, Singh V.K. and Josh V. (2014). Forecasting of late blight of potato in Tarai region of Uttarakhand using JHULSACAST model. Potato J., 41(2): 95-104.

Santosh K, MD Nadeem A, Santosh K, Mahesh K and Tribhuwan K. (2021). Influence of weather parameters on alternaria leaf blight severity of makhana under the agro-climate of Koshi region of Bihar. J. Agrometeorol., 23 (1): 54-59.
Das, S., Pandey V., Patel H.R. and Patel K.J. (2011). Effect of weather parameters on pest-disease of okra during summer season in middle-Gujarat. $J$. Agrometeorol., 13(1):38-42.

Shtienberg D. (2010). Applications of epidemiology in the management of Ascochyta blight in chickpea and lentil. In: Compendium of Chickpea and Lentil Diseases and Pests. APS Press, St Paul, Minnesota, USA. Pp 22.

Singh B.P., Ahmad I., Sharma V.C. and Shekhawat G.S. (2000). A computerized forecast of potato late blight in western Uttar Pradesh. J. Indian Potato Assoc., 27: 25-34.

Wilcoxson R.D, Skovmand B and Atif A.H. (1975). Evaluation of wheat cultivars for their ability to retard development of stem rust. Ann. Appl. Biol., 80:275-281. 